\title{
Corrigendum: Design and Implementation of the Irie Homes Toolbox: A Violence Prevention, Early Childhood, Parenting Program
}

\section{OPEN ACCESS}

Edited and reviewed by: Jane Fisher,

Monash University, Australia

${ }^{*}$ Correspondence:

Helen Baker-Henningham h.henningham@bangor.ac.uk

Specialty section This article was submitted to Public Health Education and Promotion,

a section of the journal Frontiers in Public Health

Received: 18 November 2020 Accepted: 01 December 2020 Published: 13 January 2021

Citation:

Francis $T$ and Baker-Henningham $H$ (2021) Corrigendum: Design and Implementation of the Irie Homes Toolbox: A Violence Prevention, Early Childhood, Parenting Program. Front. Public Health 8:630819. doi: 10.3389/fpubh.2020.630819

\section{Taja Francis $^{1}$ and Helen Baker-Henningham ${ }^{1,2 *}$ \\ ${ }^{1}$ Caribbean Institute for Health Research, University of the West Indies, Kingston, Jamaica, ${ }^{2}$ School of Psychology, Bangor University, Bangor, United Kingdom}

Keywords: violence prevention, parent training, intervention development, early childhood, behavior change, low-and middle-income country

\section{A Corrigendum on}

Design and Implementation of the Irie Homes Toolbox: A Violence Prevention, Early Childhood, Parenting Program

by Francis, T., and Baker-Henningham, H. (2020). Front. Public Health 8:582961. doi: $10.3389 /$ fpubh.2020.582961

In the original article, there was a mistake in Table 9 as published. Two rows are missing in the published article: the row with information relating to session five, and the row with the subheading for sessions six and seven (Managing Misbehavior). The corrected Table 9 appears below.

The authors apologize for this error and state that this does not change the scientific conclusions of the article in any way. The original article has been updated.

Copyright () 2021 Francis and Baker-Henningham. This is an open-access article distributed under the terms of the Creative Commons Attribution License (CC BY). The use, distribution or reproduction in other forums is permitted, provided the original author(s) and the copyright owner(s) are credited and that the original publication in this journal is cited, in accordance with accepted academic practice. No use, distribution or reproduction is permitted which does not comply with these terms. 
TABLE 9 | Session content of the Irie Homes Toolbox.

\begin{tabular}{|c|c|c|c|}
\hline Session & Key topic & Core content & Child-led play activity \\
\hline \multicolumn{4}{|c|}{ PROMOTING POSITIVE BEHAVIOR } \\
\hline 1 & Praise & $\begin{array}{l}\text { Paying attention to your child's positive behavior. } \\
\text { Spending individual time (Irie Time) with your child. } \\
\text { Praising yourself. }\end{array}$ & Coloring \\
\hline 2 & $\begin{array}{l}\text { Praise throughout the } \\
\text { day }\end{array}$ & $\begin{array}{l}\text { Giving your child positive attention during daily } \\
\text { activities by describing what your child is doing and } \\
\text { responding to your child. } \\
\text { Involving your child in household chores. } \\
\text { Taking time out of the day to do something you like } \\
\text { (Me time). }\end{array}$ & Blocks \\
\hline \multicolumn{4}{|c|}{ PREVENTING MISBEHAVIOR } \\
\hline 3 & Clear instructions & $\begin{array}{l}\text { How to give your child clear instructions. } \\
\text { Knowing your child. }\end{array}$ & $\begin{array}{l}\text { Picture book (My } \\
\text { School Day) }\end{array}$ \\
\hline 4 & $\begin{array}{l}\text { Why children } \\
\text { misbehave and } \\
\text { teaching household } \\
\text { rules }\end{array}$ & $\begin{array}{l}\text { Understanding the reasons for child misbehavior. } \\
\text { Explicitly teaching your child the behavior you } \\
\text { want/household rules. } \\
\text { Giving your child choice and independence. }\end{array}$ & Blocks and animal \\
\hline 5 & Emotions & $\begin{array}{l}\text { Understanding how your own emotions affect the } \\
\text { way you respond to your child's behavior. } \\
\text { Ways to calm down when feeling angry. } \\
\text { Labeling your child's emotions. } \\
\text { Turtle technique to help your child control his/her } \\
\text { anger. }\end{array}$ & $\begin{array}{l}\text { Picture book (My } \\
\text { Emotions) }\end{array}$ \\
\hline
\end{tabular}

\section{MANAGING MISBEHAVIOR}

6

7

$\begin{array}{ll} & \text { Managing } \\ & \text { misbehavior 2 }\end{array}$

Managing
misbehavior 2

\section{Managing}

misbehavior 1

anger.

Redirecting your child's attention and behavior.

Withdrawing attention from attention-seeking

behaviors.

Giving your child positive attention after dealing with

a misbehavior.

How to use Chillax (timeout for misbehavior).

Giving appropriate consequences.

Giving your child positive attention after using

Chillax or other consequences.

Problem-solving - applying the strategies learnt to

different child behaviors.
Blocks, animals, and a vehicle

Pretend play (kitchen set)

\section{SUPPORTING HOMEWORK}

8

Helping with

homework
Establishing a homework routine.

Scaffolding your child when doing homework.

How to give your child positive and corrective feedback.
Picture book (My Day with Mommy) 